\title{
THE NEED TO ESTABLISH SPECIALIZED MEDICAL COURTS FOR
}

\section{RELIABLE MEDICAL JUSTICE}

\section{Dr Rajankumar V. Bhagora}

\section{INTRODUCTION}

Medical science is vast and complex. To understand it requires basic medical science education and training for continuously for some specific period and for better management of patients it requires enough experience of implementation of medical science knowledge on patient.

When something goes wrong with patient, to understand the reason, it requires detail study of circumstances and conditions of patient. It is difficult to make out without enquiring in detail of the case whether it is misfortune or a negligence or complication of disease itself .This decision making is crucial for administering justice and it must be accurate, precise and timely.

The decision making is important for administration of justice to both doctors and consumers of medical services. Judges of consumer courts, civil courts and criminal courts may not be always be having experience in deciding cases of negligence.

Supreme court in Martin FD'souza vs Mohd Ishfaq civil appeal no. 3541 of 2002 observed that judges are not experts in medical science ,rather they are layman. ${ }^{1}$

Due to consumerism and judicial activism, there is steep rise in litigations against doctors. The ease of filling suits in consumer courts has lead to heavy backlog of cases in courts.

\footnotetext{
${ }^{1}$ Martin FD'souza vs Mohd Ishfaq (2009) scc 3541
} 
Consumer courts are not able to deliver justice in time in medical negligence cases and so litigations consume lot of time, money and energy. The current tort system and consumers courts are slow, cumbersome and yields often unpredictable results.

Better option and alternative is establishment of Medical courts characterized by the use of specially trained judges, independent expert witnesses and predictable damage awards system. ${ }^{2}$

\section{CURRENT STATUS OF CONSUMER COURTS}

It's ironical .Consumer courts were conceived, 30 years ago, in1986, as a dedicated and speedier alternative to civil courts, but they have come to resemble latter.

The story of decaying of consumers courts is reflected in the time taken to settle the case

\section{HEALTH COURTS SALIENT FEATURES:}

Unreliable justice has a particularly pernicious affect in health care, where it chills communication between doctors and patients - lessening patient safety and encourages the practice of defensive medicine, where doctors order tests and procedures to protect themselves from lawsuits.

To restore a foundation of trust we need medical courts, aimed not at stopping lawsuits but at making lawsuits reliable to protect whoever is right.

In medical courts, expert judges with special training would resolve healthcare disputes.

The salient features of medical court are

$1 \quad$ Specially trained judges

2 Independent expert witnesses

3 predictable damage award

\footnotetext{
${ }^{2}$ Martin,keith, Physicians Practice Journal 20,issue 1 Jan 2010
} 


\section{TORT REFORMS REQUIRED FOR MEDICAL COURTS ${ }^{3}$}

1. Barriers to bringing suits: It includes prescreening panels, certificate of merit requirements, expert witness certification, limits on advocates fees

2. Limiting compensation : caps for non economic damages

3. Changing system of Payment of damages: periodic vs. lump sum payments and eliminating joint and several liability

\section{SCOPE OF PROBLEM}

1 Frequency of litigations and its impact on practice:

The rise of frequency of suits has great impact on the manner the medical practice is done .It becomes more defensive and thus leading to high cost of healthcare.

2 Insurance cost :

Liability insurance premiums for physician especially for high risk specialties are highly affected by medical liability lawsuits.

3 The reality of suits vs. the ideal

The main purpose of a medical liability system is to compensate those who are injured due to wrongful acts, usually negligence, and to act as a deterrent and disincentive towards such acts so that the practitioner acts thoughtfully, skillfully and carefully.

4 Suit length: Suit length averages about 3 years but can last much longer. Suits are often not brought on until a year or more has passed from the time of injury, so the time to adjudication can be in many cases, five years or more during which the patient has no payment

5 Suit volume and future effect of healthcare:

\footnotetext{
${ }^{3}$ Joel E.chodos,MD Volume 1 No 1 Columbia medical review
} 
The volume of litigations claims have steadily grown in last 3 decades. The size of award is also not uniform. Healthcare policy and health care insurance coverage have changed lot

6 Economic costs: claim payouts and legal expenses:

When there is judgment in favour of plaintiff, money that actually goes to plaintiff are often only about $50 \%$ of the court award, with the rest going towards legal fees and other administrative expenses.

$7 \quad$ Emotional and non-emotional costs:

The emotional costs are harder to quantify but are very real. They overshadow the work of doctors, undermine their confidence, and hinder effective day to day relationships with patients. Medical litigations actions often haunt defendants daily. Even you win, you lose because of the tremendous time and energy spent in defending actions and the fact that doctors reputations are often impaired after malpractice suit. In addition it is possible for physician to lose their liability insurance even if they ultimately prevail in an action: they may be dropped by an insurer due to the number of claims being field even if no liability is ever found.

8 Judges limitations: When a case goes to trial, the plaintiff must show, in the case of negligence that the defendant had a duty that was breached, that the breach was the actual and proximate cause of injury, and that damages resulted.

Typically large amounts of scientific and medical evidence are presented. The question arises whether judges have sufficient knowledge to adequately weigh specialist scientific and technical evidence presented with conflicting interpretation.. Can they separate "REAL" science from "JUNK" science?

\section{MEDICAL COURTS RATIONALE}


Medical courts can potentially obviate the problems discussed earlier. Medical courts with narrowly focused jurisdictions offer judges with special knowledge and experience in medical science law and handle only certain types of cases in contradistinction to general courts which have gamut of cases.

Decision making is vested in special judges with scientific/medical training. Experts are chosen by the court rather than by each side so that there are no competing experts each with an allegiance to one side.

Its expected benefits are

1. Improved and more precise decision making due to greater judicial knowledge and expertise in medical science subject matter.

2. Reduced case backlog and faster adjudication.

3. Greater knowledge and familiarity with similar cases can also results in greater uniformity and consistency of decision making

4. It can reduce costs and save time.

5. Greater uniformity of court's decision can also result in reduced litigation

\section{ADVANTAGES OF HEALTH COURTS:}

\section{Judicial and Legal Efficiency}

Medical negligence litigation is complex with much technical detail. Delegating such cases to special courts honed in such area will unburden the consumer courts. The special courts are likely better and more quickly able to negotiate the difficulties of such litigation due to its experience.

\section{Judicial Expertise}

Specialized judges would, by nature of narrow scope of their work, have greater expertise. They would likely be better at evaluating scientific evidence and less dependent on experts to formulate judgment.

\section{Uniformity of Decision Making}


Special courts, staffed with a smaller number of judges and tasked with one specialty, are more likely to have greater uniformity of judgment and rulings. Predictability of judgment for a given set of facts would be an advantage

\section{Decreased Litigations}

The existence of a specialized court ,by creating greater uniformity of judgment and application of law, is likely to diminish false and frivolous litigations

\section{Extended Care Compensation Plans for Injured Parties}

Most settlements or awards are not structured to provide for ongoing care of injured patient over his remaining lifetime. A lump sum award is often left to plaintiff's management. A Medical court may be better able to coordinate and administer extended care compensation plans. This would help avoid situations where plaintiff, because of poor planning, might run out of money several years after award and the become dependent on public resources.

\section{Establishing Judicial Parameters for Standards of Medical Care}

Medical courts could over time establish precedents regarding standards of care for given medical services under variety of scenarios. This in turn could set both the patient and doctors expectations concerning what is and is not negligence. They could facilitate the development of databases concerning patient injury to encourage open and accessible knowledge of injuries and to develop patient safety protocols.

\section{Decreasing Administrative Costs}

The uniformity of decision making and in time decision of case will definitely reduce overall cost of litigation.

\section{8. $\quad$ Reduced Defensive Medicine}


Because of fear of wrong litigations doctor goes for extra investigations and procedure that add to cost of healthcare. Litigations take years to resolve and carry heavy financial as well as emotional costs for doctors.

Defensive medicine specifically involves a focus on anticipating legal liability and trying to protect against it. It has become de facto "standard operating procedure" in most medical professionals.

\section{DISADVANTAGES OF MEDICAL COURTS:}

\section{Chance for special interest groups to have undue influence}

A medical court with a select number of judges and a limited group of qualified experts, who are likely to appear repetitively, leaves the potential opportunity for courtroom bias by judges who become very familiar with the experts practicing before them. Experts also gain advantage by getting to know the judges well and learning what works and does not work with them, which can lead to an advantage for those practitioners appearing before the courts. Finally, there is a chance for special interest groups such as bar association, hospital unions and liability insurers to exert undue influence on selection process for such judges.

\section{Limited number of courts}

Specialized courts would almost always be less plentiful than general courts and further apart geographically, which could cause access problems, especially for those with constrained finances or in more rural area.

\section{Judge retention and attraction}

A specialized court have limited appeal for a judge seeking to advance his or her career. The ability to recruit and retain high quality judges may be limited except for those with a special interest in the area. 


\title{
CONCLUSIONS
}

The civil courts and consumer courts are ineffective and incompetent to handle medical negligence case in efficient manner to administer reliable medical justice to both patients and doctors. Consumer courts failed to be speedier alternative to civil courts as it was assumed.

A specialty court system like medical court that establishes a more precise precedent body of law for standards of care for various illnesses would result in greater uniformity of decision making, greater predictability and consequently greater faith in the system from both healthcare practitioners and patients

I conclude that, given the existing problems with medical negligence litigations and little likelihood that this problem will improve if the system is left alone, medical courts would be a significant asset in administrating justice and equity to injured patients.

It will also discourage or at least rapidly dispose of suits with little real basis. Thus it will stop substantial expenditures and save time and energy.

\author{
Dr Rajankumar V. Bhagora \\ Research Scholar \\ School of Law at Gujarat University \\ drrajanmeera@yahoo.com \\ M : 9925034409
}

